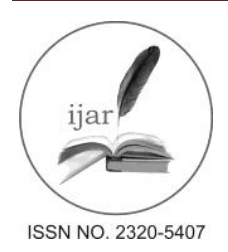

Journal homepage:http://www.journalijar.com

Journal DOI: $\underline{10.21474 / I J A R 01}$

INTERNATIONAL JOURNAL

OF ADVANCED RESEARCH

RESEARCH ARTICLE

\title{
GROWTH, BIOMASS, CARBON SEQUESTRATION AND SOIL NUTRIENT DYNAMICS UNDER PINE FOREST IN NORTH-WEST HIMALAYAS.
}

"Rupinder Kaur ${ }^{1}$ and Simrat Kaur'.

1. Faculty of Botany, Uttaranchal College of Science and Technology, Dehradun (Uttarakhand) - 248001, India.

2. Faculty of Chemistry, Mata Gujri College, Fatehgarh Sahib (Punjab) -140406, India.

\section{Manuscript Info Abstract}

Manuscript History:

Received: 15 April 2016

Final Accepted: 29 May 2016

Published Online: June 2016

Key words:

Pinus roxburghii, carbon sequestration, carbon allocation, nutrient dynamic and biomass, phytosociology

*Corresponding Author

Rupinder Kaur.
Pinus roxburghii is the most dominant forest type present in North-West Himalayas. Pine forest accounted for the total vegetation biomass of 156.7 $\mathrm{Mg} / \mathrm{ha} /$ year during present study. Total carbon stock in pine forest was 69.52 $\mathrm{Mg} / \mathrm{ha} /$ year which accounted for carbon sequestration of $255.13 \mathrm{Mg} / \mathrm{ha} /$ year. Carbon allocation in different components of Pinus roxburghii was 54.22 per cent, 53.74 per cent, 53.07 per cent and 50.75 per cent in stem, roots, branches and leaves, respectively. Phyto-sociological studies revealed that Parthenium hysterophorus had lowest frequency (0.3\%) while Chrysopogon montanus $(1.35 \%)$ had maximum frequency. Species abundance varied from $1.0 / 25 \mathrm{~m}^{2}$ or 400 herbs or shrubs/ha to $3.28 / 25 \mathrm{~m}^{2}$ or 1312 herbs/shrubs or grasses/ha. A/F ratio ranged from 1.11 (Rubus ellipticus) to 10.0 (Partheniumhysterophorus and Veronica cinerea). Soil organic carbon, N, P, $\mathrm{K}, \mathrm{pH}$, Electrical conductivity and bulk density were analysed from top soil profile $(0-15 \mathrm{~cm})$ to sub-soil profile $(30-60 \mathrm{~cm})$. Soil organic carbon varied from $0.24 \%$ to $0.77 \%$ and it decreased depth wise.Nitrogen, potassium and electrical conductivity at various soil depths varied from 194.32 to 280.0 $\mathrm{kg} / \mathrm{ha}, 128.1 \mathrm{~kg} / \mathrm{ha}$ to $269.2 \mathrm{~kg} / \mathrm{ha}$ and $1.09 \mathrm{dSm}^{-1}$ to $1.22 \mathrm{dSm}^{-1}$, respectively and they also decreased depth wise. Soil $\mathrm{pH}$ was acidic and it ranged from 6.50 to 6.72 . Available phosphorus and bulk density varied from 0.18 to 0.30 $\mathrm{kg} / \mathrm{ha}$ and $0.43-1.23 \mathrm{~g} \mathrm{~cm}^{-3}$, respectively and increased depth wise.

Copy Right, IJAR, 2016,. All rights reserved.

\section{Introduction:-}

Trees play a vital role in mitigating the diverse effects of environmental carbon degradation and increasing concentration of carbon dioxide in the atmosphere. Trees promote sequestration of carbon into soil and plant biomass. Therefore tree based land use practices could be viable alternatives to store atmospheric carbon dioxide due to their cost effectiveness, high potential of carbon uptake and associated environmental as well as social benefits (Dhruw et al., 2009). Increasing levels of carbon dioxide in the atmosphere during the past few decades has drawn the attention of the scientific community towards the process of carbon storage and soil organic carbon store. Concentration of atmospheric carbon dioxide can be lowered either by reducing emissions or by enabling the storage of carbon dioxide in the terrestrial ecosystem. An ecosystem plays very important role in storing and cycling of carbon. Soil also plays very important role in the carbon cycle by storing it in the form of soil organic carbon. Most of the carbon enters the ecosystem through the process of photosynthesis in the leaves. After the litter fall, the detritus is decomposed and forms soil organic carbon by microbial process (Post and Kwon, 2000). The Himalayan forest vegetation ranges from tropical deciduous forests in the foothills to timberline. Pinus roxburghii is the most important resin pine sp. of India and also a source of fuelwood. In India chir pine covers are of 8,69,000 hectares that extends from J\&K, Himachal, Uttar Pradesh, West Bengal and Arunachal Pradesh (Anon, 2004). In Himachal Pradesh about $1346 \mathrm{~km}^{2}$ area is under chir pine forest. 
Carbon sequestration potential depends upon the biological productivity, which in turn depends upon interaction between species, climate, topography and management practices imposed. Thus carbon density and sequestration potential varies from place to place, which needs to be worked out on region to region and species to species basis. Carbon sequestration potential differs with the kind of land use system. Finding low-cost methods to sequester carbon is emerging as a major international policy goal in the context of global climate change (Montagnini and Nair, 2004). Therefore, the need is to assess the potential of different land- management options which can fulfill both environmental and economic goals. The need is to find a suitable land-use system which, on the one hand, will fulfill our requirements of food, fodder and timber and on the other has environmental benefits. Carbon sequestration depends upon biomass production capacity, which in turn depends upon interaction between edaphic, climatic and topographic factors of an area. Hence results obtained at one place may not be applicable to another. Therefore, region-based potential of different land use needs to be worked out.

In the present investigation it has been postulated that pine forest in Himachal Pradesh have different impacts, especially in terms of carbon sequestration, productivity and nutrient distribution. The need is to study these aspects, which have been envisaged in the present study. In addition the allocation pattern of carbon, nutrients dynamics $(\mathrm{N}$, $\mathrm{P}$ and $\mathrm{K}$ ) in the soils and phyto-sociological attributes for shrub and herb layers in pine forest were also investigated.An attempt was made for analyzing the pine forest in relation to physico-chemical properties of soil and carbon sequestration potential in North-West Himalaya.

\section{Materialsand methods:-}

\section{Study site:-}

The present study on growth, biomass, carbon allocation and carbon sequestration was undertaken in the Pine forest inBajhol village, Solan district (H.P.), during the growing seasons (July-November) of the years 2010 and 2011.

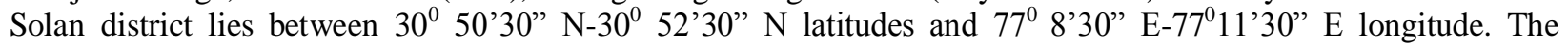
vegetation mainly comprises of sub-alpine Chir-pine types (Verma et al., 2007). The forests in Solan district have pure and mixed stands of Chir-pine. The area is a transitional zone between sub-tropical to sub-temperate with maximum temperature risings up to $37.8^{0} \mathrm{C}$ during summer. Annual rainfall varies from 1000-1400 mm, majority of which is received during monsoons, i.e. July to mid-September. The minimum and maximum temperature varies from $3^{0} \mathrm{C}$ during winter (January) to $33^{\circ} \mathrm{C}$ during summer (June), whereas mean annual temperature is $19^{\circ} \mathrm{C}$. Soil is inceptisols and typic entrochrepts type and texture is gravelly, sandy and loamy (Devi et al., 2013).

\section{Tree growth and biomass estimation:-}

The study area was divided equally into five replications of $10 \times 10 \mathrm{~m}$ and in each replication all trees were selected.Total 42 trees were enumerated in order to determine the various morphological attributes, diameter at breast height (Dbh), height of the trees, crown length, crown spread and crown index by using standard methods.Aboveground tree biomass was estimated using volumetric equations given by Forest Survey of India (FSI, 1996) as it was not possible to excavate trees manually. Volume was transformed into biomass by multiplying with specific gravity of 0.49 (FSI, 1996). Belowground biomass (root) of Pinus roxburghii was determined by multiplying aboveground biomass with a factor of 0.20 (IPCC, 2003). Various species of shrubs, grasses and herbs present in the pine forest, were alsocollected, identified and their phytosociological analysis (density, frequency, abundance and A/F ratio) was done by using the method given by Phillips (1959) and Misra (1969). Biomass of shrubs, grasses, herbs and litter in pine forest was calculated by harvesting them from the five quadrates of 50x50 $\mathrm{cm}$ laid in triplicates by randomized sampling.

\section{Carbonallocation in different tree components:-}

It was estimated by dry combustion method given by Gallardo and Merino (1993)using Muffle furnace. In this method plant components (branch, leaves, stem wood and root) were oven dried and crushed. $5 \mathrm{~g}$ of plant sample was taken in silica crucible and kept at $800^{\circ} \mathrm{C}$ for 5 hours in muffle furnace for combustion. After cooling, sample was weighed and percent organic carbon was calculated.

\section{Soil analysis:-}

$$
\text { Percent Organic Carbon }=\frac{\text { Weight of loss } \times 0.58}{\text { Sample weight }} \times 100
$$

Soil samples were collected randomly from five sites in three replications $(50 \times 50 \mathrm{~cm})$ from pine forest at three different soil depths of 0-15 cm, 15-30 cm and 30-60 cm. Samples from all the five sites at each soil depth from 
study site were analyzed for the distribution of nutrient elements and other parameters. Collected soil samples were dried and sieved through $2 \mathrm{~mm}$ mesh before analysis. Soil was analyzed for \% organic carbon, available N, available $\mathrm{P}$, available $\mathrm{K}, \mathrm{pH}$, electrical conductivity and bulk density. Different soil parameters studied and the methods adopted to analyze them are given in Table 1.

Table 1:- Parameters and methods adopted for the analysis of Soil.

\begin{tabular}{|c|l|l|}
\hline S. N. & Parameters & Methods \\
\hline 1. & \% Organic carbon & Walkely and BlackMethod (1934) \\
\hline 2. & Available N & Micro-Kjeldhal method by Chapmann and Pratt (1961) \\
\hline 3. & Available P & Spectrophotometer method by Watambe and Olsen (1965) \\
\hline 4. & Available K & Flame photometer method by Jackson (1967) \\
\hline 5. & $\mathrm{pH}$ & pH meter method by Jackson (1973) \\
\hline 6. & Electrical conductivity & Digital conductivity meter method by Jackson (1973) \\
\hline 7. & Bulk density & Specific gravity bottle method by Singh (1980) \\
\hline
\end{tabular}

\section{Carbon sequestration:-}

The aboveground (AGB) and belowground (BGB) tree biomass was summed to get the total biomass. Carbon stock was obtained by multiplying biomass with a factor of 0.45 (Woomer, 1999; Sheikh et al., 2011b). Carbon stock of pine forest was determined by adding carbon stock of trees, shrubs, herbs, and litter. Carbon inventory of pine forest was calculated by using the formula given below.

Carbon stock = Biomass x 0.45 (Woomer, 1999 and Sheikh et al., 2011b)

Carbon sequestered $=$ Biomass carbon stock x 3.67 (Rajput, 2010)

Soil carbon pool inventory $=\left[\right.$ Soil bulk density $\left(\mathrm{g} \mathrm{cm}^{-3}\right) \times$ soil depth $\left.(\mathrm{cm}) \times \mathrm{C}(\%)\right] \times 100$ (Nelson and Sommers, 1996).

\section{Statistical analysis:-}

The data on soil parameterswas subjected for two-way analysis of variance (ANOVA) to determine the significance of results between different five study sites at three soil depths in pine forest and Bonferroni's multiple comparison post-test were performed at the significance level of $\mathrm{p}<0.05$.

\section{Results and discussion:-}

Tree morphology, biomass and carbon allocation:-

Within the pine forest, five sites were selected randomly and trees were measured for morphological features. Results on tree growth and biomass attributes viz; dbh, height, clear bole height, number of branches, crown length, crown spread, crown index, total tree biomass and total vegetation biomass in the pine forest are given in Tables 2 and 3. It is evident from former table that mean height and crown spread in Pinus roxburghii were $20.58 \mathrm{~m}$ and 1.55 $\mathrm{m}$, respectively. Crown length and crown index were $5.83 \mathrm{~m}$ and $4.88 \mathrm{~m}$, respectively. On an average tree had a dbh of $20.3 \mathrm{~cm}$ with a clear bole of $14.59 \mathrm{~m}$. The biomass of different components of trees as well as of understorey shrubs, grasses etc. is given in Table 3. Tree biomass, shrub biomass and herb/grass biomass in pine forest was 144.9, 1.41 and $5.86 \mathrm{Mg} / \mathrm{ha} /$ year, respectively, while litter biomass was $4.56 \mathrm{Mg} / \mathrm{ha} /$ year. Total vegetation biomass was $156.7 \mathrm{Mg} / \mathrm{ha} /$ year and which contributed for the total carbon stock $(69.52 \mathrm{Mg} / \mathrm{ha} / \mathrm{year})$ in pine forest. Carbon sequestered by the pine forest was $255.13 \mathrm{Mg} / \mathrm{ha} /$ year.

Biomass of leaf litter, herbs and grass recorded was found low in pine forest. This could be because of acidic nature of pine forest soil which inhibits the growth of other vegetation. Nautiyal and Singh (2013) reported higher carbon stock densities for AGTB (above ground tree biomass), BB (below-ground biomass), LHG (leaf litter, herbs and grass), DWS (dead wood and fallen stumps), AGSB (above-ground sapling biomass) and soil organic carbon compared to present studies. Total carbon density of $986.93 \mathrm{Mg} / \mathrm{ha}$ was found in pine forest of Nandprayag. However it is evident that the above-ground biomass in chir-pine forest is higher than the range reported by Chaturvedi and Singh (1987) and Sharma et al. (2010) for Himalayan Pinus roxburghii. The carbon stock values vary according to the location, plant species, age of the stand, aboveground input received from leaf litter, decomposition of fine roots below ground, management practices and other operating ecological factors. Land use and soil management practices can significantly influence soil organic carbon dynamics and carbon flux of the soil (Batjes, 1996; Tian et al., 2002; Rasse et al., 2006; Van et al., 1997). 
Table 2:-Morphological attributes of trees under pine forest during two years of study.

\begin{tabular}{|c|c|c|c|c|c|c|c|}
\hline Sites & $\begin{array}{c}\text { dbh } \\
(\mathbf{c m})\end{array}$ & Height $(\mathbf{m})$ & $\begin{array}{c}\text { Clear bole } \\
(\mathbf{m})\end{array}$ & $\begin{array}{c}\text { Number of } \\
\text { branches }\end{array}$ & $\begin{array}{c}\text { Crown } \\
\text { Spread (m) }\end{array}$ & $\begin{array}{c}\text { Crown } \\
\text { length }(\mathbf{m})\end{array}$ & $\begin{array}{c}\text { Crown } \\
\text { Index }(\mathbf{m})\end{array}$ \\
\hline S1 & $23.95 \pm 3.89$ & $20.24 \pm 0.71$ & $13.87 \pm 0.38$ & $25.33 \pm 7.69$ & $1.74 \pm 0.34$ & $5.58 \pm 0.21$ & $3.54 \pm 0.88$ \\
\hline S2 & $23.42 \pm 3.03$ & $20.69 \pm 0.49$ & $15.77 \pm 0.48$ & $20.33 \pm 6.89$ & $1.84 \pm 0.69$ & $4.92 \pm 0.97$ & $3.59 \pm 1.45$ \\
\hline S3 & $25.54 \pm 4.67$ & $21.34 \pm 0.81$ & $15.79 \pm 0.52$ & $19.67 \pm 5.33$ & $1.74 \pm 0.40$ & $5.54 \pm 1.11$ & $3.58 \pm 1.00$ \\
\hline S4 & $20.99 \pm 4.24$ & $21.50 \pm 0.30$ & $16.19 \pm 0.45$ & $26.67 \pm 7.26$ & $1.57 \pm 0.74$ & $5.31 \pm 0.74$ & $5.01 \pm 1.72$ \\
\hline S5 & $7.63 \pm 0.66$ & $19.17 \pm 0.47$ & $11.36 \pm 0.05$ & $20.67 \pm 7.45$ & $0.90 \pm 0.02$ & $7.82 \pm 0.43$ & $8.70 \pm 0.35$ \\
\hline $\begin{array}{c}\text { Mean } \pm \\
\text { S.E. }\end{array}$ & $20.30 \pm 3.2$ & $20.58 \pm 0.55$ & $14.59 \pm 0.37$ & $22.53 \pm 6.92$ & $1.55 \pm 0.43$ & $5.83 \pm 0.69$ & $4.88 \pm 1.08$ \\
\hline
\end{tabular}

Values are Mean \pm standard error

In the present study, shrub and herb/grass biomass varied under the influence of the Pine trees. These variations can be due to variation in the light interception, moisture regime, nutrient dynamics, acidic $\mathrm{pH}$ of soil etc. In general, shrub, herb/grass biomass was maximum under the sites which had higher humus content. The presence of humus play important role in under storey biomass as reported by Adhiakri et al. (1995) and Zhu et al. (2010). Rana and Singh (1990) showed that the understorey (shrubs + herbs) accounted for $1.5 \%$ of the total forest biomass (432.8 t/ha) in Pinus roxburghii plantation located in Kumaun Himalaya of Uttarakhand.

Table 3:-Biomass and carbon stock in trees under pine forest during two years of study.

\begin{tabular}{|c|c|c|c|c|c|c|c|c|c|c|}
\hline Sites & $\begin{array}{l}\text { Tree } \\
\text { above } \\
\text { ground } \\
\text { biomass } \\
\text { (Mg/ha) }\end{array}$ & $\begin{array}{l}\text { Tree } \\
\text { below } \\
\text { ground } \\
\text { biomass } \\
\text { (Mg/ha) }\end{array}$ & $\begin{array}{c}\text { Total } \\
\text { treebio } \\
\text { mass } \\
\text { (above+ } \\
\text { below) } \\
\text { Mg/ha }\end{array}$ & \begin{tabular}{|l} 
Above \\
ground \\
carbon \\
stock \\
$(\mathrm{Mg} / \mathrm{ha})$
\end{tabular} & $\begin{array}{c}\text { Below } \\
\text { ground } \\
\text { carbon } \\
\text { stock } \\
(\mathrm{Mg} / \mathrm{ha})\end{array}$ & \begin{tabular}{|c} 
Total \\
carbon \\
stock \\
(above+ \\
below) \\
Mg/ha
\end{tabular} & \begin{tabular}{|c|} 
Shrub \\
biomass \\
(Mg/ha)
\end{tabular} & \begin{tabular}{|c} 
Herb/ \\
grass \\
biomass \\
(Mg/ha)
\end{tabular} & $\begin{array}{l}\text { Total } \\
\text { vegetation } \\
\text { biomass } \\
\text { (Mg/ha) }\end{array}$ & $\begin{array}{l}\text { Total } \\
\text { vegetation } \\
\text { carbon } \\
\text { stock }\end{array}$ \\
\hline S1 & $\begin{array}{l}113.2 \\
\pm 10.4\end{array}$ & $\begin{array}{l}22.64 \\
\pm 2.09\end{array}$ & $\begin{array}{l}135.8 \\
\pm 12.5\end{array}$ & $\begin{array}{l}50.94 \\
\pm 4.71\end{array}$ & $\begin{array}{l}10.19 \\
\pm 0.94\end{array}$ & $\begin{array}{l}61.13 \\
+5.65\end{array}$ & $\begin{array}{c}1.41 \\
\pm 0.02\end{array}$ & $\begin{array}{c}5.67 \\
\pm 0.01\end{array}$ & 142.92 & 64.31 \\
\hline S2 & $\begin{array}{l}123.2 \\
\pm 0.81\end{array}$ & $\begin{array}{l}24.64 \\
\pm 0.16\end{array}$ & $\begin{array}{l}147.8 \\
\pm 0.97\end{array}$ & $\begin{array}{l}55.45 \\
\pm 0.36\end{array}$ & $\begin{array}{l}11.09 \\
\pm 0.07\end{array}$ & $\begin{array}{l}66.54 \\
\pm 0.44\end{array}$ & $\begin{array}{c}1.37 \\
\pm 0.03\end{array}$ & $\begin{array}{c}5.34 \\
\pm 0.03\end{array}$ & 166.91 & 75.10 \\
\hline S3 & $\begin{array}{r}124.4 \\
\pm 1.85\end{array}$ & $\begin{array}{l}24.89 \\
\pm 0.37\end{array}$ & $\begin{array}{l}149.3 \\
\pm 2.22\end{array}$ & $\begin{array}{c}56.0 \\
\pm 0.83\end{array}$ & $\begin{array}{l}11.20 \\
\pm 0.17\end{array}$ & $\begin{array}{r}67.20 \\
\pm 1.00\end{array}$ & $\begin{array}{c}1.52 \\
\pm 0.02\end{array}$ & $\begin{array}{c}6.78 \\
\pm 0.02\end{array}$ & 157.64 & 70.93 \\
\hline S4 & $\begin{array}{r}124.7 \\
\pm 0.09\end{array}$ & $\begin{array}{l}24.59 \\
\pm 0.02\end{array}$ & $\begin{array}{l}149.6 \\
\pm 0.10\end{array}$ & $\begin{array}{l}56.13 \\
\pm 0.04 \\
\end{array}$ & $\begin{array}{r}11.23 \\
\pm 0.01 \\
\end{array}$ & $\begin{array}{l}67.36 \\
\pm 0.05 \\
\end{array}$ & $\begin{array}{c}1.48 \\
\pm 0.02\end{array}$ & $\begin{array}{c}6.13 \\
\pm 0.02\end{array}$ & 157.3 & 70.78 \\
\hline S5 & $\begin{array}{r}118.3 \\
\pm 3.61\end{array}$ & $\begin{array}{c}23.6 \\
\pm 0.72\end{array}$ & $\begin{array}{l}141.9 \\
\pm 4.33\end{array}$ & $\begin{array}{l}53.24 \\
\pm 1.63\end{array}$ & $\begin{array}{l}10.65 \\
\pm 0.33\end{array}$ & $\begin{array}{l}63.88 \\
\pm 1.95\end{array}$ & $\begin{array}{c}1.27 \\
\pm 0.01\end{array}$ & $\begin{array}{c}5.39 \\
\pm 0.01\end{array}$ & 148.62 & 66.87 \\
\hline $\begin{array}{l}\text { Mean } \\
\pm \text { S.E }\end{array}$ & $\begin{array}{l}120.7 \\
\pm 3.36\end{array}$ & $\begin{array}{l}24.08 \\
\pm 0.67\end{array}$ & $\begin{array}{l}144.9 \\
\pm 4.03\end{array}$ & $\begin{array}{c}54.35 \pm \\
1.51\end{array}$ & $\begin{array}{l}10.87 \\
\pm 0.30\end{array}$ & $\begin{array}{l}65.22 \\
\pm 1.81\end{array}$ & $\begin{array}{c}1.41 \\
\pm 0.02\end{array}$ & $\begin{array}{c}5.86 \\
\pm 0.01\end{array}$ & $\begin{array}{r}154.5 \\
\pm 2.95\end{array}$ & $\begin{array}{c}72.27 \\
\pm 1.42\end{array}$ \\
\hline
\end{tabular}

Values are Mean \pm standard error

Carbon allocation observed in different components of $P$. roxburghii for the two years of study is presented in Table 4. The carbon allocation varied in terms of site, components and year of study. In P. roxburghii averagecarbon allocation was maximum in the stem $(54.22 \%)>$ roots $(53.74 \%)>$ branch $(53.07 \%)$ and leaves $(50.75 \%)$ during two years of study. Average carbon allocation in stem varied from 53.03 to 55.42 percent, in roots from 51.33 to 56.16 percent, in branches from 51.80 to 54.34 percent and in leaves from 47.69 to 53.82 percent, respectively, from year 2010 to 2011. These results are in conformity with Ganeshaiah et al. (2003) who reported that carbon allocation in $P$. roxburghii and $P$. wallichiana was highest in stem wood $(46.32 \%$ and $46.18 \%)$ followed by leaves (43.46\% and $43.08 \%)$ and bark (44.07\% and 42.06\%). Wani and Qaisar (2014) reported carbon allocation in Cedrus deodara was in the order: stem wood $(46.39 \%)>$ root $(46.17 \%)>$ branch $(46.05 \%)>$ and leaf $(42.81 \%)$. Similarly, in Fraxinusfloribunda and Ulmuswallichiana carbon allocation was in order of: stem wood $(43.21 \%$ and $43.66 \%$, respectively) $>\operatorname{root}(43.01 \%$ and $43.21 \%$, respectively) $>$ branch $(42.42 \%$ and $43.03 \%$, respectively) $>$ leaf $(36.70 \%$ and $36.41 \%$, respectively). 
Table 4:-Carbon allocation in different components of Pinus roxburghiiduring two years of study.

\begin{tabular}{|c|c|c|c|c|c|c|c|c|}
\hline \multirow{2}{*}{ Sites } & \multicolumn{2}{|c|}{ Leaf carbon (\%) } & \multicolumn{2}{|c|}{ Stem carbon (\%) } & \multicolumn{2}{c|}{ Branch carbon (\%) } & \multicolumn{2}{c|}{ Root carbon (\%) } \\
\cline { 2 - 9 } & $\mathbf{2 0 1 0}$ & $\mathbf{2 0 1 1}$ & $\mathbf{2 0 1 0}$ & $\mathbf{2 0 1 1}$ & $\mathbf{2 0 1 0}$ & $\mathbf{2 0 1 1}$ & $\mathbf{2 0 1 0}$ & $\mathbf{2 0 1 1}$ \\
\hline S1 & 41.82 & 54.85 & 53.89 & 56.27 & 51.30 & 55.14 & 51.61 & 56.40 \\
& \pm 0.04 & \pm 0.70 & \pm 0.12 & \pm 0.07 & \pm 0.28 & \pm 0.50 & \pm 0.03 & \pm 0.04 \\
\hline S2 & 48.79 & 54.99 & 53.62 & 56.13 & 51.41 & 54.62 & 53.01 & 56.47 \\
& \pm 1.10 & \pm 0.54 & \pm 0.62 & \pm 0.17 & \pm 0.18 & \pm 0.82 & \pm 0.69 & \pm 0.07 \\
\hline S3 & 47.69 & 51.94 & 51.55 & 56.03 & 52.36 & 53.53 & 50.81 & 56.60 \\
& \pm 1.46 & \pm 0.94 & \pm 0.42 & \pm 0.25 & \pm 0.16 & \pm 0.90 & \pm 0.96 & \pm 0.07 \\
\hline S4 & 45.34 & 53.41 & 51.85 & 54.91 & 52.17 & 54.01 & 50.17 & 56.39 \\
& \pm 1.21 & \pm 0.77 & \pm 0.40 & \pm 0.53 & \pm 0.20 & \pm 0.55 & \pm 1.37 & \pm 0.04 \\
\hline S5 & 46.94 & 53.90 & 52.55 & 53.78 & 51.61 & 54.40 & 49.73 & 54.96 \\
& \pm 1.41 & \pm 0.43 & \pm 0.23 & \pm 1.20 & \pm 0.14 & \pm 0.20 & \pm 0.35 & \pm 0.75 \\
\hline Mean & 47.69 & 53.82 & 53.03 & 55.42 & 51.80 & 54.34 & 51.33 & 56.16 \\
\pm S.E. & \pm 0.75 & \pm 0.55 & \pm 0.72 & \pm 0.47 & \pm 0.20 & \pm 0.27 & \pm 0.69 & \pm 0.30 \\
\hline
\end{tabular}

Values are Mean \pm standard error

The present study results are in agreement with trends observed by many other workers like Shephered and Montagnini (2001), Dhruw et al. (2009), Jana et al. (2009), Navar (2009) and Fonseca et al. (2012), who reported carbon per cent was higher in stem wood, followed by root, branch, bark and leaf. Kraenzel et al. (2003) reported that woody tissues like trunk, roots, branches and twigs have higher carbon content than soft tissues like leaves, flowers and fine roots.

\section{Phyto-sociological attributes for shrub and herb layer:-}

In pine forest the biodiversity in terms of grasses, herbs and shrubs were studied and results are presented in Table 5. Fifteen species of herbs, shrubs and grasses were observed in the pine forest under study. Species density was 4556 herbs, shrubs or grasses/ha. Individual species density ranged between 160 herbs or shrubs/ha (Lepidium sp., Murraya koiengii, Parthenium hysterophorus, Viola serpensand Veronica cinerea) to 424 herbs or shrubs/ha (Adiantum pedatum). Minimum frequency was of Parthenium hysterophorus $(0.3 \%)$ while Chrysopogon montanus (1.35\%) had maximum frequency. Abundance varied from 400 herbs or shrubs/ha (Carrisa carandus and Rubus ellipticus) to 1312 herbs or shrubs or grasses/ha (Themada anathera). A/F ratio ranged from 1.11 (Rubus ellipticus) to 10.0 (Parthenium hysterophorus and Veronica cinerea). Singh et al. (2009) reported the quantitative information of pine forest in Garhwal Himalayas and found that the associated ground floras with pine trees were Asparagusracemosus, Rhus parviflora, Lantana camara, Carrisa spinarum, Mallotus phillipensis, Nepta hindostana, Artemisia scorpia and Colebrookia appositifolia. Singh et al. (2013) also reported that the most dominating shrub species associated with pure chir pine forest was Eupatorium cannabinum (6200 shrubs/ha) followed by Asparagusracemosus. Inspite of the fact that chir pine forests in western Himalaya and Central Himalaya grew as natural monoculture there was variability with respect to under storey species. This is attributed to facts like geology of region, tree species age and density aspect, etc. 
Table 5:-Phytosociological attributes of vegetation in pine forest during two years of study.

\begin{tabular}{|c|c|c|c|c|c|}
\hline Sr. No. & Species & $\begin{array}{c}\text { Density(Herb or } \\
\text { shrub/25 m²) }\end{array}$ & $\begin{array}{l}\text { Frequency } \\
\text { (F) }(\%)\end{array}$ & $\begin{array}{c}\text { Abundance (A) } \\
\text { Herb or } \\
\text { shrub/25m } \\
\end{array}$ & $\begin{array}{l}\mathrm{A} / \mathbf{F} \\
\text { ratio }\end{array}$ \\
\hline 1 & Adiantum pedatum & $1.06(424)$ & 0.75 & $3.20(1280)$ & 4.26 \\
\hline 2 & Bidens alba & $0.26(104)$ & 0.45 & $1.30(520)$ & 2.95 \\
\hline 3 & Carrisa carandus & $0.26(104)$ & 0.60 & $1.00(400)$ & 4.26 \\
\hline 4 & Cheilanthes lanosa & $0.73(292)$ & 0.75 & $3.20(1280)$ & 4.26 \\
\hline 5 & Chrysopogon montanus & $1.86(744)$ & 1.35 & $3.11(1244)$ & 2.30 \\
\hline 6 & Lepidium $s p$. & $0.40(160)$ & 0.60 & $1.50(600)$ & 2.50 \\
\hline 7 & Myrsine africana & $0.50(200)$ & 0.60 & $2.00(800)$ & 3.33 \\
\hline 8 & Murraya koiengii & $0.40(160)$ & 0.45 & $3.00(1200)$ & 6.60 \\
\hline 9 & $\begin{array}{c}\text { Parthenium } \\
\text { hysterophorus }\end{array}$ & $0.40(160)$ & 0.30 & $3.00(1200)$ & 10.00 \\
\hline 10 & Potentilla indica & $0.60(240)$ & 0.60 & $2.25(900)$ & 3.75 \\
\hline 11 & Rubus ellipticus & $0.46(184)$ & 0.90 & $1.00(400)$ & 1.11 \\
\hline 12 & Themada anathera & $3.06(1224)$ & 2.10 & $3.28(1312)$ & 1.56 \\
\hline 13 & Veronica cinerea & $0.40(160)$ & 0.60 & $1.50(600)$ & 10.00 \\
\hline 14 & Viola serpens & $0.40(160)$ & 0.45 & $3.00(1200)$ & 6.60 \\
\hline 15 & Woodfordia fruiticosa & $0.60(240)$ & 0.90 & $1.50(600)$ & 1.66 \\
\hline \multicolumn{2}{|r|}{ Total value } & $11.39(4556)$ & 12.40 & $25.45(13536)$ & 65.14 \\
\hline & Mean value & $0.75(303.73)$ & 0.82 & $2.12(902.4)$ & 4.34 \\
\hline
\end{tabular}

Data given in parenthesis are quantification per hectare (density and abundance are of shrubs or herbs per hectare):-

\section{Soil characteristics:-}

Soil $\mathrm{pH}$, bulk density and available phosphorus increased from top to bottom while soil organic carbon, available nitrogen, available potassium and electrical conductivity decreased from top to bottom during both years of study as shown in Table 6.The organic carbon in pine forest during present study varied from $0.24 \%$ to $0.77 \%$. It decreased from top soil profile $(0-15 \mathrm{~cm})$ to sub-soil profile $(30-60 \mathrm{~cm})$. Soil organic carbon showed a significant variation between different study sites and soil depths. In the earlier studies, Dalai (1997) studied soil of Chirpine forest of Oachghat and Kandaghat areas of Solan District (HP) and found organic carbon of 1.34 and $1.05 \%$, respectively. Sharma (1991) analysed the soil under Chirpine forest of Solan forest division and found soil organic carbon between 0.17 to $3.37 \%$. Jina etal. (2011) reported that organic carbon ranged from 1.65 to $2.76 \%$, respectivelyin degraded and non-degraded pine forest in Kumaun Himalayas which is higher in comparison to present study. The influence of topography, climatic conditions, soil composition, litter quality and its decomposition rate and species composition or vegetation type affect spatial distribution of soil organic carbon (Schulp et al., 2008).

Nitrogen measured at various soil depths in different sites in pine forest showed non- significant variation and it ranged from 194.32 to $280.0 \mathrm{~kg} / \mathrm{ha}$ and decreased depth wise. Malik (1992) reported that available $\mathrm{N}$ varied from 94.0 to $233.0 \mathrm{ppm}$ in Chirpine forests of Solan district. Many other researchers found variability in nitrogen in chir pine forests of Himachal Pradesh (Sud and Sharma, 1982; Murthy et al., 1985). Dalai (1997) analysed soil nitrogen under Chirpine forest of Oachghat and Kandaghat and found average nitrogen of $337.98 \mathrm{~kg} \mathrm{ha}^{-1}$ and $324.05 \mathrm{~kg} \mathrm{ha}^{-1}$, respectively, which is higher in comparison to present work. Available phosphorus in pine forest varied from 0.18 to $0.30 \mathrm{~kg} / \mathrm{ha}$ significantly during the present study. Phosphorus content increased with depth in soil layers of pine forest. Singh et al. (1990) found the same trend in chir pine forest of Doon valley. Dalai (1997) reported high phosphorus (30.42 and $27.33 \mathrm{~kg} \mathrm{ha}^{-1}$ for Oachghat and Kandaghat, respectively) compared to present study.

Potassium ranged from $128.1 \mathrm{~kg} / \mathrm{ha}$ to $269.2 \mathrm{~kg} / \mathrm{ha}$ significantly during two years of study anddecreased from top soil profile to sub-soil profile. Dalai (1997) reported average potassium content of $562.95 \mathrm{~kg} \mathrm{ha}^{-1}$ and $425.98 \mathrm{~kg} \mathrm{ha}^{-1}$ for Oachghat and Kandaghat, respectively in the chir pine forest. Singh et al. (2009) reported potassium ranged from 89.98 to 116.48 per cent in pine-mixed forest in Garhwal Himalaya. Kaushal (1992) reported more available K in surface than sub-surface soils of Kinnaur district of Himachal Pradesh. The variability in K is understandable as it is a known fact that the Himalayan topography and soil structure varies from place to place. 
Table 6:- Physico-chemical properties at different soil layers in Pine forest.

\begin{tabular}{|l|c|c|c|c|c|c|}
\hline \multirow{2}{*}{ Soil depth } & \multicolumn{2}{|c}{ Depth $\mathbf{0 - 1 5} \mathbf{~ c m}$} & \multicolumn{2}{c|}{ Depth 15-30 cm } & \multicolumn{2}{c|}{ Depth 30-60 cm } \\
\cline { 2 - 7 } Parameters & $\mathbf{1}^{\text {st }}$ year & $\mathbf{2}^{\text {nd }}$ year & $\mathbf{1}^{\text {st }}$ year & $\mathbf{2}^{\text {nd }}$ year & $\mathbf{1}^{\text {st }}$ year & $\mathbf{2}^{\text {nd }}$ year \\
\hline \% Organic & $0.47 \pm 0.03^{\#}$ & $0.77 \pm 0.10$ & $0.34 \pm 0.02$ & $0.59 \pm 0.11$ & $0.24 \pm 0.03$ & $0.36 \pm 0.05$ \\
carbon & $(0.03)^{*}$ & $(0.001)$ & $(0.003)$ & $(0.002)$ & $(0.005)$ & $(0.001)$ \\
\hline Available & $267.8 \pm 27.4$ & $280.0 \pm 28.9$ & $212.64 \pm 10.0$ & $227.7 \pm 17.1$ & $194.32 \pm 7.46$ & $224.76 \pm 13.2$ \\
Nitrogen & $(9.33)$ & $(9.33)$ & $(0.75)$ & $(9.33)$ & $(0.98)$ & $(9.33)$ \\
\hline Available & $0.18 \pm 0.03$ & $0.23 \pm 0.01$ & $0.24 \pm 0.01$ & $0.24 \pm 0.01$ & $0.30 \pm 0.01$ & $0.30 \pm 0.03$ \\
Phosphorus & $(0.01)$ & $(0.01)$ & $(0.01)$ & $(0.01)$ & $(0.01)$ & $(0.01)$ \\
\hline Available & $215.8 \pm 28.0$ & $269.21 \pm 12.0$ & $166.4 \pm 31.33$ & $257.2 \pm 12.9$ & $128.1 \pm 26.7$ & $242.33 \pm 14.2$ \\
Potassium & $5(0.001)$ & $(0.001)$ & $(0.002)$ & $(0.002)$ & $(0.003)$ & $(0.003)$ \\
\hline pH & $6.50 \pm 0.11$ & $6.58 \pm 0.06$ & $6.63 \pm 0.13(0$. & $6.66 \pm 0.08$ & $6.72 \pm 0.03$ & $6.67 \pm 0.06$ \\
& $(0.01)$ & $(0.02)$ & $02)$ & $(0.02)$ & $(0.01)$ & $(0.03)$ \\
\hline Bulk density & $1.15 \pm 0.01$ & $0.40 \pm 0.02$ & $1.18 \pm 0.01$ & $0.43 \pm 0.02$ & $1.23 \pm 0.01$ & $0.48 \pm 0.01$ \\
& $(0.02)$ & $(0.02)$ & $(0.01)$ & $(0.02)$ & $(0.03)$ & $(0.01)$ \\
\hline Electrical & $1.17 \pm 0.01$ & $1.22 \pm 0.01$ & $1.14 \pm 0.01$ & $1.16 \pm 0.01$ & $1.09 \pm 0.03$ & $1.14 \pm 0.20$ \\
conductivity & $(0.01)$ & $(0.02)$ & $(0.01)$ & $(0.01)$ & $(0.02)$ & $(0.03)$ \\
\hline
\end{tabular}

\#Values are Mean \pm Standard error

*Values inside the parenthesis are $\mathbf{p}<0.05=$ Significant

Soil $\mathrm{pH}$ in the present investigation varied significantly from 6.50 to 6.72 . It increased from the top soil profile to sub-soil profile. Slightly acidic to neutral $\mathrm{pH}$ could be ascribed to pine needles rich in resins which on decomposition release organic acids in soil. Sharma (1991) analysed the soil under Chirpine forest of Solan forest division and found that the soil had 5.0 to $8.0 \mathrm{pH}$. Malik (1992) reported $\mathrm{pH}$ value ranged from 5.1 to 7.9 and increased with depth under all Chirpine association in forest of Solan Division. Dalai (1997) found that the Chirpine forest soil had average $\mathrm{pH}$ value between 5.87 and 5.74 for Oachghat and Kandaghat forests, respectively. The reduction in $\mathrm{pH}$ can be attributed to accumulation and subsequent slow decomposition of organic matter, which releases acids (de Hann 1977; Singh et al., 2009). The electrical conductivity in pine forest varied from $1.09 \mathrm{dSm}{ }^{-1}$ to $1.22 \mathrm{dSm}^{-1}$. Electrical conductivity decreased depth wise and showed significant variation between study sites and soil depth. Similar results were reported earlier by Shah et al. (2013) in pine forest in Solan district of Himachal Pradesh. Bulk density ranged from $0.43-1.23 \mathrm{~g} \mathrm{~cm}^{-3}$.

\section{Conclusion:-}

The present study reveals that study area under investigation is rich in carbon stock both in terms of plantation as well as soil. Total vegetation carbon stock in pine forest was $69.52 \mathrm{Mg} / \mathrm{ha} /$ year which accounted for carbon sequestration of $255.13 \mathrm{Mg} / \mathrm{ha} /$ year. Soil carbon inventory pool was $1117.8 \mathrm{Mg} / \mathrm{ha} / \mathrm{year}$. Forest based land use systems could be among the best methods for storing atmospheric $\mathrm{CO}_{2}$ because of its cost effectiveness and other social and economic benefits. Among the tree components stem wood contributed for 54.22\%, roots contributed for $53.74 \%$, branches contributed for $53.07 \%$ and leaves for the 50.75\% carbon allocation. Nutrient storage ranged from $0.24-0.77 \%$ organic carbon, 194.32 to $280.0 \mathrm{~kg} \mathrm{~N} \mathrm{ha}^{-1}, 0.18$ to $0.30 \mathrm{~kg} \mathrm{P} \mathrm{ha}^{-1}, 128.1$ to $269.2 \mathrm{~kg} \mathrm{~K} \mathrm{ha}^{-1}, 6.50$ to 6.72 $\mathrm{pH}, 1.09$ to $1.22 \mathrm{dSm}^{-1}$ electrical conductivity and 0.43 to $1.23 \mathrm{~g} \mathrm{~cm}^{-3}$ bulk density. Therefore it can be concluded from the present research that pine forests plays very potent and promising role in the building up of carbon stock and consequently climate change mitigation. Pine forests are very vital natural carbon reserve that has to be protected and conserved. The further study is needed on tree-soil interactions and litterfall with different tree management practices for maximizing sequestration of carbon and attaining sustainable production from Pinus roxburghii stands.

\section{References:-}

1. Adhikari, B.S., Rawat, Y.S., and Singh, S.P. (1995). Structure and function of high altitude forests of central Himalaya I. Dry matter dynamics. Annals of Botany. 75:237-48.

2. Batjes, N.H. (1996). Total carbon and nitrogen in the soils of the world. European Journal of Soil Science.47:151-63.

3. Chapmann, H.T. and Pratt, P.E. (1961).Method of analysis for soil, plant and water. University of California, USA. 
4. Chaturvedi, O.P. and Singh, J.S. (1987).Structure and function of Pine forest in central Himalaya. Dry matter dynamics. Annals of Botany.60:237-52.

5. Dalai, D. (1997). Productivity of grasses in relation to site quality in Pinusroxburghii plantations [M.Sc Thesis]. Dr. Y. S. Parmar University of Horticulture and Forestry, Nauni, Solan (H.P.) India.

6. de Hann, S. (1977). Humus, its formation, its relation with the mineral part of the soil and its significance for soil productivity. In: Organic matter studies, vol 1. International Atomic Energy Agency, Vienna.p. 21-30.

7. Devi, B., Bhardwaj, D.R., Panwar, P., Pal, S., Gupta, N.K. and Thakur, C.L. (2013).Carbon allocation, sequestration and carbon dioxide mitigation under plantation forests of north western Himalaya, India. Annals of Forest Research.56(1):123-35.

8. Dhruw, S.K., Singh, L.J. and Singh, A.K. (2009).Storage and sequestration of carbon by leguminous and nonleguminous trees on red lateritic soil of Chhattisgarh. Indian Forester. 135(4):531-38.

9. Forest survey of India. (1996). Volume Equations for Forests of India, Nepal and Bhutan, Forest Survey of India Ministry of Environment and Forests, Govt. of India.

10. Fonseca, W., Alice, F.E. and Benayas, J.M.R. (2012).Carbon accumulation and above ground and below ground biomass and soil of different age native forest plantations in the humid tropical low lands of Costa Rica. New Forests. 43:197-211.

11. Gallardo, A. and Merino, J. (1993). Leaf decomposition in two Mediterranean ecosystems of Southwest Spain: influence of substrate quality. Ecology.74:152-161.

12. Intergovernmental Panel on Climate Change. (2003).Good Practice Guidance for Land use, Land use Change and Forestry. Published by the institute for global environmental strategies for the IPCC. Publishers institute for global environmental strategies, Japan.

13. Jackson, M.L. (1967). Soil chemical analysis. Prentice- Hall, Englewood cliffs, NJ.

14. Jackson, M.L. (1973).Soil chemical analysis. Prentice Hall of India Private Limited New Delhi.

15. Jana, B.K., Biswas, S., Majumder, M., Roy, P.K. and Mazumdar, A. (2009).Carbon sequestration rate and aboveground biomass carbon potential of four young species. Journal of Ecology and Natural Environment. 1(2):15-24.

16. Jina, B.S., Bohra, C.S., Lodhiyal, L.S. and Sah, P. (2011).Soil characteristics in oak and pine forests of Indian central Himalaya E-international Scientific Research Journal.3(1):19-22.

17. Kaushal, R. (1992). Studies on the physico-chemical properties of deodar association [M.Sc dissertation]. Dr. Y. S. Parmar University of Horticulture and Forestry, Nauni, Solan (H.P.) India.

18. Kraenzel, M., Castillo, A., Moore, T. and Potuin, C. (2003). Carbon storage of harvest age teak (Tectona grandis) plantations, Panama. Forest Ecology and Management.173:213- 25.

19. Malik, P.C. (1992). Studies on the physico-chemical properties of Chirpine association [M.Sc dissertation]. Dr. Y. S. Parmar University of Horticulture and Forestry, Nauni, Solan (H.P.) India.

20. Misra, R. (1969). Ecological Workbook. Oxford I. B.H. Publishing Company. Calcutta, India.

21. Montagnini, F. and Nair, P.K.R. (2004). Carbon sequestration: an underexploited environmental benefit of agroforestry systems. Agroforestry Systems. 61:281-95.

22. Murthy, J.R., Sharma, A.K. and Prakash, O. (1985).Soil site relationship for pine in Garhwal Himalayas. In: Khosla PK, Khurana DK, Atul, editors. Production and conservation forestry. Indian Society of Tree Scientists, Solan, India.35-58.

23. Nautiyal, N. and Singh, V. (2013).Carbon stock potential of oak and pine forests in Garhwal region in Indian Central Himalayas.2(1):43-48.

24. Navar, J. (2009). Allometric equations for tree species and carbon stocks for forests of Northwestern Mexico. Forest Ecology and Management.257: 427-34.

25. Negi, J.D.S., Manhas, R.K. and Chauhan, P.S. (2003). Carbon allocation of different components of some tree species of India: A new approach for carbon estimation. Current Science.85:1528-31.

26. Nelson, D.W. and Sommers, L.E. (1996). Total carbon, organic carbon and organic matter. In: Sparks DL et al. editors. Method of soil analysis. Part 3. Chemical methods. Soil Science Society of America, Madison, Wisconsin, 961-1010.

27. Phillips, E.A. (1959). Methods of vegetation study. A Holtdryden book. Henry Holt and Co. Inc.

28. Post, W.M. and Kwon, K.C. (2000). Soil carbon sequestration and land use change process and potential. Global Change Biology.6:317-27.

29. Rajput, B.S. (2010). Bio-economic appraisal and carbon sequestration potential of different land use systems in temperate north-western Himalayas [Ph.D Thesis]. Dr. Y. S. Parmar University of Horticulture and Forestry, Nauni, Solan (H.P.) India. 
30. Rana, B.S. and Singh, R.P. (1990). Plant biomass and productivity estimates for central Himalayan mixed Banj oak (Quercus leucotrichophora A. camus)-chir pine (Pinusroxburghii). Indian Forester. 116(3):220-26.

31. Rasse, D.P., Dignac, M.F., Bahri, H., Rumpel, C., Mariotti, A. and Chenu, C. (2006). Lignin turnover in an agricultural field: from plant residues to soil-protected fractions. European Journal of Soil Science.57:530-38.

32. Saralch, H.S. (1994). Nutrient dynamics and biomass production potential of Eucalyptus tereticornis Smith in high density short rotation systems [M.Sc dissertation]. Dr. Y. S. Parmar University of Horticulture and Forestry, Solan (H.P.) India.

33. Schulp, C.J.E., Nabuurs, G.J., Verburg, P.H. and Waal, R.W. (2008).Effect of tree species on carbon stocks in forest floor and mineral soil and implications for soil carbon inventories. Forest Ecology and Management.256:48290 .

34. Sheikh, M.A., Kumar, M., Bussman, R.W. and Todaria, N.P. (2011b). Forest carbon stocks and fluxes in physiographic zones of India. Carbon Balance and Management.6:15.

35. Sharma, B. (1991).Studies on relationship of soil physico-chemical properties with chir pine association [M.Sc dissertation]. Dr. Y.S. Parmar University of Horticulture and Forestry, Nauni, Solan (H.P.) India.

36. Sharma, C.M., Baduni, N.P., Gairola, S., Ghildiyal, S.K. and Suyal, S. (2010). The effect of slope aspects on the forest composition, community structure and soil nutrient status of some major natural temperate forest types of Garhwal Himalaya. Journal of Forest Research.21(3):331-37.

37. Shah, S., Sharma, D.P., Pala, N.A. and Tripathi, P. (2013). Carbon stock and density of soils under chir pine (Pinus roxburghii Sargent) forests of Solan forest division, Himachal Pradesh. Indian Journal of Soil Conservation. 41(3):279-86.

38. Shepherd, D. and Montagnini, F. (2001). Aboveground carbon sequestration in the humid tropics. Journal of Tropical Forest Science.13(3):450-59

39. Singh, R. A. (1980). Soil physical analysis. Kalyani Publishers, New Delhi.

40. Singh, G., Gill, H.S. and Abrol, I.P. (1990). Salt affected soils and their management for agroforestry. Proceeding International Symposium on National Resources management organized by Indian Society of Agronomy. February 610; 11:64.

41. Singh, H., Kumar, M. and Sheikh, M.A. (2009).Distribution pattern of Oak and pine along altitudinal gradients in Garhwal Himalaya. Nature and Science.7(11):81-85.

42. Sud, K.C. and Sharma, R.C. (1982). Organic carbon and nitrogen status of brown hill soils of Shimla district. Journal of Indian Society of Soil Science. 30:216-18.

43. Tian, H., Melillo, J.M., Kicklighter, D.W. (2002). Regional carbon dynamics in monsoon Asia and implications for the global carbon cycle. Global Planet Change.37:201-17.

44. Van, N.M., Cerri, C., Woomer, P.L., Nugroho, K. and Bernoux, M. (1997). Soil carbon dynamics in the humid tropical forest zone. Geoderma.79:187-225.

45. Verma, K.S., Bhardwaj, D.R. and Chand, K. (2007). Agroforestry Systems in Himachal Pradesh. In: Puri S, Panwar P, editors. Agroforestry: Systems and practices. New India Publishing Agency, Pitam Pura. p. 67-93.

46. Walkley, A.E. andBlack, J.A. (1934).An Examination of Degtjareff Method for Determining Soil Organic Matter and a Proposed Modification of the Chromic Acid Titration Method. Soil Science.37:29-37.

47. Watambe, F.S. and Olsen, S.R. (1965). Test of an ascorbic acid method for determining phosphorus in water and $\mathrm{NaHCO}_{3}$, extract. Soil Science Society of America Proceedings.29:677.

48. Wani, N.R. and Qaisar, K.N. (2014).Carbon. Per cent in Different Components of Tree Species and Soil Organic Carbon Pool Under these Tree Species in Kashmir Valley. Current World Environment. 9(1):174-81.

49. Woomer, P.L. (1999).Impact of cultivation of carbon fluxes in woody savannas of southern Africa. Water, Air, and Soil Pollution. 70:403-12.

50. Yadav, J.S.P. (1963). Studies on soil profiles in Chakrata forest division of Uttar Pradesh. Indian Forester. 89:18-38.

51. Zhu, B., Wang, X., Fang, J., Piao, S., Shen, H., Zhao, S. and Peng, C. (2010). Altitudinal Changes in carbon storage of temperature forests on Mt. Changbai, Northeast China. Journal of Plant Research. 123(4):439-52. 